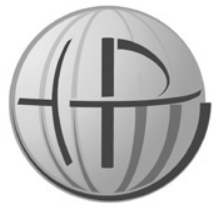

Horyzonty Polityki 2020, Vol. 11, No 34

\section{Tomasz SŁUPIK}

http://orcid.org/0000-0002-1869-1415 Uniwersytet Śląski w Katowicach

Wydział Nauk Społecznych Instytut Nauk Politycznych e-mail: tomasz.slupik@us.edu.pl

DOI: $10.35765 /$ HP.1872

\section{Tocqueville i problemy $\mathrm{z}$ naturą demokracji}

\title{
Streszczenie
}

CEL NAUKOWY: Celem naukowym jest ukazanie cech specyficznych demokracji oraz ich wpływu na kondycję współczesnej jednostki i społeczeństwa z perspektywy historii idei. Na podstawie analizy tekstów Alexisa de Tocqueville'a i jego wybitnych interpretatorów, takich jak: Pierre Manent, Michael Oakeshott.

PROBLEM I METODY BADAWCZE: Ukazanie z perspektywy historii idei istoty pojęcia demokracji zarówno w jego teoretycznym, jak i praktycznym wymiarze. Znakomita analiza demokracji poczyniona przez A. de Tocqueville’a w książce O demokracji w Ameryce od swojej premiery we Francji w latach 1835 (I tom) i 1840 (II tom) absolutnie nie straciła na znaczeniu i aktualności. Wprost przeciwnie. Ponowne odkrycie Tocqueville'a w latach pięćdziesiątych dwudziestego wieku było zasługą Raymonda Arona. Pracę nad interpretacją myśli Tocqueville’a kontynuował P. Manent-jego najwybitniejszy uczeń. Zasługi tych dwóch intelektualistów dla popularyzacji myśli A. de Tocqueville’a są bezsporne. To dzięki nim autor $O$ demokracji w Ameryce trafił najpierw do europejskiego, później światowego obiegu intelektualnego. Zatem analiza demokracji opartych na opracowaniach Tocqueville'a i jego interpretatorów jest niezwykle użyteczna do badania kondycji współczesnej demokracji.

PROCES WYWODU: Tekst zaczyna się od analizy rewolucyjnych przemian społeczeństw zachodnich - głównie Francji i USA - oraz wpływu na ich kondycję polityczna, społeczną i ekonomiczną. Później autor skupia się na omówieniu skutków, jakie niesie ze sobą demokratyczna transformacja. Chodzi przede wszystkim o zasadę suwerenności ludu, nową regułę legitymizacji władzy, która 
zastąpiła wcześniejszą zasadę suwerenności króla. Reguła ta budzi liczne kontrowersje, jest nieprecyzyjna, a współcześnie stała się pustym gestem, niewiele znaczącym rytuałem. Dalej zostaje przedstawiony swoisty paradoks demokracji, która będąc z natury zjawiskiem społecznym mającym pogłębiać więzi społeczne, prowadzi do odwrotnego skutku, ich rozluźnienia, a nawet rozpadu. $Z$ kolei w demokracji (a właściwie jej współczesnej odmianie - demokracji liberalnej) krucha równowaga pomiędzy równością i wolnością skutkuje jej licznymi deformacjami. Zatem krótka konkluzja brzmi - wolność przegrywa rywalizację z równością. Następnie autor pokazuje skutki, jakie wywołuje triumf równości. Konsekwencją tego zjawiska jest pojawienie się „człowieka masowego” z jego wszystkimi wadami. Na koniec zostaje zaprezentowane pojęcie „łagodnego despotyzmu” jako ilustracja procesu „ubezwłasnowolnienia” nowoczesnych społeczeństw i jednostek przez wszędobylskie, rozbudowane w bardzo wielu wymiarach współczesne państwo.

WYNIKI ANALIZY NAUKOWEJ: Głównym wynikiem analizy naukowej jest ukazanie przez pryzmat dzieła A. de Tocqueville', jak również jego współczesnych interpretatorów, wpływu rewolucji demokratycznej, która miała miejsce w ostatnich dwustu latach na jednostkę, społeczeństwo, państwo. Powyższe rozważania dotyczą funkcjonowania człowieka w obszarze polityki, ekonomii i kultury. Wniosek, jaki płynie z obserwacji zawartych w niniejszym artykule, jest pesymistyczny. Demokracja ma cały szereg wad, które przy pojawieniu się niesprzyjających okoliczności społeczno-ekonomicznych mogą prowadzić do deformacji, a nawet rozpadu społeczeństwa.

WNIOSKI, INNOWACJE, REKOMENDACJE: We wnioskach autor skupia się na konsekwencjach, jakie niesie ze sobą równość w demokracji. Zarówno ta, którą P. Manent określa jako „naturalną” oraz ta, którą określa, jako „wyobrażoną". W demokracji, a w demokracji liberalnej w szczególności, napięcie pomiędzy wolnością a równością prowadzi do jej rozchwiania, w ostatecznym rozrachunku do głębokiego kryzysu. W tym modelu ustrojowym - na poziomie idei, jak również praktyki politycznej - nie można tej sprzeczności ani złagodzić, ani wyeliminować. To twórcze napięcie, szczególnie przez kilka dekad po II wojnie światowej na Zachodzie przyniosło pokój, dobrobyt oraz społeczną i polityczną stabilizację. Druga dekada XXI wieku podważa ten stan rzeczy. Demokracja liberalna pod naporem negatywnych zjawisk, chociażby takich jak rozwarstwienie społeczne, ulega poważnemu kryzysowi, wskutek którego mogą wyłonić się dwa nowe modele ustrojowe: „demokracji nieliberalnej” czy też „liberalizmu niedemokratycznego".

\section{SŁowA KLUCzowe:}

demokracja, A. de Tocqueville, P. Manent, równość, człowiek masowy, łagodny despotyzm 


\title{
Abstract \\ TOCQUEVILLE AND PROBLEMS WITH THE NATURE OF DEMOCRACY
}

\begin{abstract}
RESEARCH OBJECTIVE: The scientific goal is to show the specific features of democracy and their impact on the condition of the contemporary individual and society from the perspective of the history of ideas, basing on the analysis of the texts of A. de Tocqueville is and his outstanding interpreters, such as P. Manent, M. Oakeshott.
\end{abstract}

THE RESEARCH PROBLEM AND METHODS: Showing the essence of the concept of democracy from the historical idea perspective in its theoretical and practical view. A. de Tocqueville's excellent analysis of democracy in his book "Democracy in America" since its premiere in France in 1835 (volume 1) and 1840 (volume 2) has not absolutely lost its meaning and topicality. On the contrary. The rediscovery of Tocqueville in the 1950s was due to R. Aron. P. Manent his most outstanding student continued his work on interpreting Tocqueville's thoughts. The merits of these two outstanding intellectuals for popularizing the thoughts of $\mathrm{A}$. de Tocqueville are indisputable. It is thanks to them the author of "Democracy in America" "first found its way into European and later global intellectual circulation. Thus, analysis of democracy based on the tools developed by Tocqueville and his interpreters is extremely useful for studying the condition of contemporary democracy.

THE PROCESS OF ARGUMENTATION: The text begins with an analysis of the revolutionary changes in Western societies, mainly: France and the USA and their impact on political, social and economic conditions. Later, the author focuses on discussing the effects of democratic transformation. Most of all it is about the principle of people's sovereignty, a new rule of legitimacy of power, which replaced the earlier principle of the king's sovereignty. This rule raises a lot of controversy, it is imprecise, and today it has become an empty gesture, not a significant ritual. Next, a peculiar paradox of democracy is presented, which is naturally a social phenomenon intending to deepening social ties, brings the opposite effect, their loosening and even disintegration. In turn, in a democracy (or rather its contemporary version of liberal democracy), the fragile balance between equality and freedom results in its numerous deformations. Therefore the short conclusion is: freedom loses competition with equality. Then the author shows the effects of equality triumph. The consequence of this phenomenon is the appearance of a "mass man" with all his defects. And finally, the concept of "mild despotism" is presented as an illustration of the process of " incapacitation" of modern societies and individuals by the ubiquitous modern state, expanded in many spheres.

RESEARCH RESULTS: The main result of scientific analysis is to show the impact of the democratic revolution that has taken place for over the last two hundred years on: the individual, society, form the point of A. de Tocqueville's 
work view, as well as its contemporary interpreters. The above analysis concerns the functioning of man in the area of politics, economy and culture. The conclusion of the observations contained in this article is pessimistic. Democracy has a number of disadvantages which, when socio-economic circumstances occur, can lead to deformation and even the collapse of society.

CONCLUSIONS, INNOVATIONS, AND RECOMMENDATIONS: In his conclusions, the author focuses on the consequences of equality in democracy. Both that P. Manent describes as "natural" and the second one that he describes as "imagined" as well. In democracy and mainly in liberal democracy, the tension between freedom and equality leads to its loosening and consequently to even deep crisis. In this system model, at the level of ideas as well as political practice, this contradiction cannot be alleviated or eliminated. This creative tension, especially for several decades after World War II, brought peace, prosperity, and social and political stability in the West. The second decade of the 21century undermines this state of affairs. Liberal democracy being under the pressure of negative phenomenon, such as social stratification, undergoes a serious crisis, the effect of which two new system models may occur: "illiberal democracy" or "undemocratic liberalism".

\section{KeYwORDS:}

democracy, A. de Tocqueville, P. Manent, equality, mass man, mild despotism

\section{WSTĘP}

Podstawowe pytania, jakie Tocqueville sobie stawiał w obliczu zmian, które obserwował i jednocześnie opisywał, brzmiały tak: jak wyglądać będzie społeczeństwo, które powstało w wyniku rewolucji (zarówno we Francji, jak i Stanach Zjednoczonych), jakie nowe instytucje przez to społeczeństwo zostaną powołane do życia, wreszcie jakie będą konsekwencje przeprowadzonych zmian? I nie chodzi tu o zasadę legitymizującą nową władzę, zasadę przedstawicielstwa, która ma wyartykułować różnorodność opinii istniejących w społeczeństwie i być zarazem najlepszym ich odzwierciedleniem. Rzecz cała bowiem dotyczy zjawiska o wiele poważniejszego, a mianowicie równości.

Spośród wszystkich nowych zjawisk - pisał Tocqueville - jakie przyciągnęły moją uwagę podczas pobytu w Stanach Zjednoczonych, najbardziej uderzyła mnie panująca tam powszechna równość 
możliwości (...). Im głębiej badałem społeczeństwo, tym silniej utwierdzałem się w przekonaniu, że równość możliwości jest tym podstawowym zjawiskiem, z którego wszystkie inne zdają się wywodzić, i natrafiałem nań nieustannie jako na punkt, do którego prowadziły wszystkie moje spostrzeżenia (Tocqueville, 1996a, s. 6) ${ }^{1}$.

Tak więc centralnym zagadnieniem, które określa ogół warunków panujących w społeczeństwie, jest równość będąca jednocześnie główną przyczyną pewnej społecznej „tendencji”, o której tak pisze P. Manent: „Nowa równość nie jest stanem, lecz procesem - «rosnącą egalitaryzacją warunków» - którego kres trudny jest do wyobrażenia" (Manent, 1994, s. 149). W tym jednak punkcie ujawnia się pewna ambiwalencja w podejściu Tocqueville’a do tego zjawiska, bo z jednej strony akceptuje on „marsz” równości przez nowożytną historię i jego konsekwencje, z drugiej postępy równości budzą w nim wielkie obawy i napawa lękiem. Kondycja społeczeństwa nowożytnego na pewno jest określana przez warunki społeczne, które charakteryzują się takim poziomem równości jaki nigdy w dotychczasowej historii społecznej nie miał miejsca. Z tego faktu wynikają dla społeczeństwa bardzo poważne konsekwencje. Tocqueville, opierając się na przykładzie społeczeństw amerykańskiego i francuskiego, stwierdza że są one diametralnie różne, tak jak odmienna była sytuacja obu państw. Rewolucja francuska, która dała początek nowożytnemu państwu francuskiemu, musiała najpierw zniszczyć porządek arystokratyczny i na jego gruzach zbudować nowy. Ustrój i tworzące go instytucje okazał się niestabilny, ponieważ równość to było doświadczenie,

1 „Parmi les objets nouveaux qui, pendant mon séjour aux États-Unis, ont attiré mon attention, aucun n'a plus vivement frappé mes regards que l'égalité des conditions. Je découvris sans peine l'influence prodigieuse qu'exerce ce premier fait sur la marche de la société; il donne à l'esprit public une certaine direction, un certain tour aux lois; aux gouvernants des maximes nouvelles, et des habitudes particulières aux gouvernés. Bientôt je reconnus que ce même fait étend son influence fort au-delà des moeurs politiques et des lois, et qu'il n'obtient pas moins d'empire sur la société civile que sur le gouvernement: il crée des opinions, fait naître des sentiments, suggère des usages et modifie tout ce qu'il ne produit pas. Ainsi donc, à mesure que j'étudiais la société américaine, je voyais de plus en plus, dans l'égalité des conditions, le fait générateur dont chaque fait particulier semblait descendre, et je le retrouvais sans cesse devant moi comme un point central où toutes mes observations venaient aboutir" (por. Tocqueville, 1952a, s. 7). 
które zostało narzucone społeczeństwu przemoca, a wcześniejsze rządy absolutne zwalczały jakiekolwiek jej przejawy, tak więc Francuzi w okresie Rewolucji mieli o niej bardzo mgliste pojęcie. Zupełnie inaczej rzecz ma się z Amerykanami.

Mieszkańców Stanów Zjednoczonych - pisze Tocqueville - nigdy nie dzieliły żadne feudalne przywileje, nie znali stosunków łączących pana i poddanego (...) Los Amerykanów jest osobliwy: od angielskiej arystokracji zapożyczyli ideę indywidualnych praw i upodobanie do swobód lokalnych, a potem zdołali zachować jedno i drugie, ponieważ nie musieli obalać arystokracji (Tocqueville, 1996b, s. 312)².

Amerykanie nie doświadczyli sytemu feudalnego i związanej z nim nierówności, nie musieli również pozbywać się arystokracji. Ich społeczeństwo powstało jako zbiorowość kierująca się zasadą równości od samego początku. Idea ta nie była czymś abstrakcyjnym, wprowadzanym w życie przemocą (kosztem wielu ofiar) jak we Francji, lecz częścią politycznej praktyki. W Ameryce

większość obywateli - stwierdza Tocqueville - od dawna osiągnęła mniej więcej tę samą kondycję, a równość jest faktem dawnym i uznanym (Tocqueville, 1996b s. 195) ${ }^{3}$.

W Stanach Zjednoczonych po prostu ludzie rodzą się równi i nie muszą się takimi stawać. $Z$ tej zasadniczej różnicy wyłaniają się również dwa modele demokracji. „Amerykański” - harmonijny ze stabilnymi instytucjami i stojącymi na ich straży prawami oraz

2 „Les hommes qui habitent les États-Unis n’ont jamais été séparés par aucun privilège; ils n'ont jamais connu la relation réciproque d'inférieur et de maître, et, comme ils ne se redoutent et ne se haïssent point les uns les autres, ils n'ont jamais connu le besoin d'appeler le souverain à diriger le détail de leurs affaires. La destinée des Américains est singulière: ils ont pris à l'aristocratie d'Angleterre l'idée des droits individuels et le goût des libertés locales; et ils ont pu conserver l'une et l'autre parce qu'ils n'ont pas eu à combattre d'aristocratie" (por. Tocqueville, 1952d, s. 131).

3 „Lorsque la plupart des citoyens ont depuis longtemps atteint une condition a peu près semblable, et que l'égalité est un fait ancien et admis, le sens public, que les exceptions n'influencent jamais, assigne, d'une manière générale, à la valeur de l'homme, de certaines limites au-dessus ou au-dessous desquelles il est difficile qu'aucun homme reste longtemps place" (por. Tocqueville, 1952b, s. 26). 
„francuski” - pełen wstrząsów, z ciągle zmieniającymi się wraz z kolejnymi konstytucjami ustrojami państwowymi (warto dodać, że owe zmiany najczęściej są konsekwencją zamachu stanu). W tym miejscu może rodzić się pytanie, dlaczego w dwóch wyżej opisanych przypadkach demokracja ma tak różne oblicza? Dla Tocqueville’a jest ona bowiem:

Stanem społecznym - pisze Manent - określonym przez równość warunków, a nie zespołem politycznych instytucji. Z tego samego społecznego stanu - twierdzi Tocqueville - ludy mogą wyciągnąć konsekwencje „nadzwyczajnie" różne. Jednocześnie obserwowanie życia w Stanach Zjednoczonych nauczyło go, że równość warunków stanowi fakt twórczy w odniesieniu do źródła wszelkich amerykańskich bytów społecznych i politycznych oraz że ten stan społeczny wywiera "nadzwyczajny wpływ" na wszystkie aspekty życia amerykańskiego (Manent, 1994, s. 150-151).

Tocqueville zatem nie postrzega demokracji jako zespołu instytucji, lecz jako pewien specyficzny "stan społeczny". Demokracja w ujęciu negatywnym, wedle interpretacji Tocqueville'a, na pewno jest zaprzeczeniem arystokracji i charakterystycznej dla niej zasady hierarchiczności. W aspekcie pozytywnym zaś może być albo ucieleśnieniem wolności, albo prowadzić do despotyzmu wynikającego najczęściej z wszechwładzy większości" (Tocqueville, 1996a, s. $252-266)^{4}$.

\section{WSZELKA WŁADZA POCHODZI OD LUDU?}

Jednak aby w pełni zrozumieć poglądy Tocqueville'a na demokrację, należy przytoczyć jego opinię na temat suwerenności ludu, która stanowi właściwe dopełnienie jego koncepcji. Autor Dawnego ustroju i rewolucji tak ją charakteryzuje:

Zasada suwerenności ludu nie jest w Ameryce ani ukryta, ani tylko formalna, jak to ma miejsce w pewnych krajach. Jest widoczna w obyczajach i głoszona przez prawa. Rozprzestrzenia się swobodnie i bez przeszkód można z niej wyciągnąć najskrajniejsze konsekwencje (...).

$4 \quad$ Zob. Tocqueville, 1952b, s. 76-89. 
W wielu innych krajach władza jest podzielona, pozostając jednocześnie wewnątrz społeczeństwa i poza nim. W Stanach Zjednoczonych bynajmniej tak nie jest; społeczeństwo samodzielnie rozwiązuje tu swe problemy; siła i władza istnieją tylko w jego łonie (...). Wybierając prawodawców, lud uczestniczy tym samym w kształtowaniu praw, a wybierając urzędników sprawujących władzę wykonawczą - w ich stosowaniu (...). Lud rządzi amerykańską rzeczywistością polityczną tak, jak Bóg rządzi wszechświatem; jest zarazem racją i kresem wszystkich rzeczy; wszystko pochodzi od niego i wszystko do niego powraca (Tocqueville, 1996a s. 57-59) .

Pisząc książkę o amerykańskiej demokracji Tocqueville dochodzi do wniosku, że jest ona takim "stanem społecznym”, w którym rolę głównej „zasady regulacyjnej” pełni polityczna kategoria „suwerenności ludu". Dwoistość demokracji stanowiąca praktyczny skutek zastosowania obu zasad opiera się na dwóch następujących przekonaniach. Według pierwszego w demokracji żaden obywatel nie musi być posłuszny drugiemu i nikt nie może narzucać swojej woli innym. Jest

5 „En Amérique, le principe de la souveraineté du peuple n'est point caché ou stérile comme chez certaines nations; il est reconnu par les moeurs, proclamé par les lois; il s'étend avec liberté et atteint sans obstacles ses dernières conséquences. S'il est un seul pays au monde où l'on puisse espérer apprécier à sa juste valeur le dogme de la souveraineté du peuple, l'étudier dans son application aux affaires de la société et juger ses avantages et ses dangers, ce pays-là est assurément l'Amérique. J'ai dit précédemment que, dès l'origine, le principe de la souveraineté du peuple avait été le principe générateur de la plupart des colonies anglaises d'Amérique. Il s'en fallut de beaucoup cependant qu'il dominât alors le gouvernement de la société comme il le fait de nos jours. Deux obstacles, l'un extérieur, l'autre intérieur, retardaient sa marche envahissante. Il ne pouvait se faire jour ostensiblement au sein des lois, puisque les colonies étaient encore contraintes d'obéir à la métropole; il était donc réduit à se cacher dans les assemblées provinciales et surtout dans la commune. Là il s'étendait en secret.[...] Il y en a d'autres où la force est divisée, étant tout à la fois placée dans la société et hors d'elle. Rien de semblable ne se voit aux États-Unis; la société y agit par elle même et sur elle-même. Il n'existe de puissance que dans son sein; on ne rencontre même presque personne qui ose concevoir et surtout exprimer l'idée d'en chercher ailleurs. Le peuple participe à la composition des lois par le choix des législateurs, à leur application par l'élection des agents du pouvoir exécutif; on peut dire qu'il gouverne lui-même, tant la part laissée à l'administration est faible et restreinte, tant celle-ci se ressent de son origine populaire et obéit à la puissance dont elle émane. Le peuple règne sur le monde politique américain comme Dieu sur l'univers. Il est la cause et la fin de toutes choses; tout en sort et tout s'y absorbe" (por. Tocqueville, 1952a, s. 52-53). 
to przesłanka wynikająca ze „społecznego stanu równości”. Drugie przekonanie dotyczy właściwie zinterpretowanej zasady "suwerenności ludu", która mówi, że człowiek nie jest zależny od nikogo, może słuchać tylko samego siebie lub przedstawiciela, którego sam wybierze, jednakże w każdej chwili jest w stanie go odwołać. Innymi słowy, pierwsza przesłanka precyzuje, czym demokracja nie jest, definiuje ją w sposób negatywny, druga z kolei określa, czym demokracja jest lub być powinna, określając jej aspekt pozytywny. Taki sposób ujęcia zaproponowany przez Tocqueville'a ma zasadniczy wpływ zarówno na „,wizerunek”, jak i samoświadomość nowoczesnych społeczeństw. Znany co najmniej od czasów Georga W.F. Hegla podział na społeczeństwo cywilne i państwo rozumiane jako zespół instytucji nie ma już tak zasadniczego znaczenia. Stało się tak za sprawą utożsamienia celu, który w ramach określonego zespołu poglądów, czy też programu, zarówno państwo, jak i społeczeństwo cywilne pragną zrealizować. Zanika podział na wymiar polityczny i społeczny, ponieważ rozróżnienie to niczemu już nie służy.

Obserwowanie demokracji w Ameryce - konstatuje Manent - doprowadziło Tocqueville'a do podważenia podstawowych kategorii doktryny liberalnej (Manent, 1994, s. 152).

Mocne słowa, jednak kluczowe dla interpretacji dzieła Tocqueville'a. Bo skoro tocqueville' owska interpretacja idei demokracji swych źródeł poszukuje poza porządkiem politycznym, to również abstrahuje od porządku społecznego. Można by rzec, że poszukuje swych fundamentów w jakimś przedpolitycznym czy też przedspołecznym fakcie. Aby zrozumieć właściwie owo zjawisko, musimy odwołać się do pewnego spostrzeżenia, które na temat Tocqueville'a poczynił Manent.

Słowem kluczowym jest tutaj wpływ. Odkąd ludzie żyją w społeczeństwach, te utrzymują się w spoistości jedynie dzięki wpływowi, dzięki oddziaływaniu, jakie ludzie wzajemnie na siebie wywierają. Im bardziej ów wpływ i owo oddziaływanie są żywe i zróżnicowane, tym społeczeństwo jest bardziej cywilizowane i tym bardziej człowiek rozwija swoje zdolności. Demokracja wszelako, ponieważ pragnie stworzyć samą siebie $\mathrm{w}$ oparciu o jednostki będące sobie równe, czyli takie, które wzajemnie sobie nie rozkazują a nawet nie wywierają na siebie wpływu - wszelki wpływ przekształca w sposób 
naturalny w rozkaz - oddziela ludzi od siebie, stawia ich obok siebie, bez wspólnej więzi. Demokracja prowadzi zatem do „dezintegracji” społeczeństwa (Manent, 1994, s. 153).

\section{ASPOŁECZNY CHARAKTER DEMOKRACJI}

Niebezpieczeństwo rozpadu zaniku więzi społecznych, czy mówiąc wprost społeczna anomia były dla Tocqueville'a realnymi zagrożeniami. W demokracji bowiem „naturalne” więzi zostają zastąpione systemem formalnych współzależności. Paradoks Tocqueville'a polega na tym, że to co inni postrzegają jako zagrożenie, dla niego jest szansą. Jego widzenie Stanów Zjednoczonych chroni go przed pesymizmem konserwatystów, którzy w zatomizowanym społeczeństwie widzą zagrożenie przede wszystkim dla wolności i na tym poprzestają. Tocqueville $w$ swoich rozważaniach idzie dalej i akceptuje optymizm liberałów, którzy twierdzą że ów zanik więzi można będzie pokonać w momencie, kiedy każda jednostka będzie samodzielnie decydowała o charakterze relacji, jakie łączą ją z innymi. Gdy w demokratycznym ustroju społecznym ludzie izolują się od siebie, zamykają się w swojej prywatności, obojętni na losy pozostałych, musi pojawić się jakiś podmiot, który zmusi ich do wyjścia poza wąskie ramy prywatności. Z funkcji tej najlepiej jest w stanie wywiązać się państwo, które stworzy płaszczyznę i na niej będą realizowane wspólne interesy. Poziom zorganizowania tego państwa może być różny. We Francji obowiązuje „model scentralizowany", w którym większość podstawowych funkcji jest właśnie przez nie realizowana, zresztą za przyzwoleniem obywateli, którzy wolą powierzyć swoje problemy administracji (która ich zdaniem w sposób szybki i skuteczny je rozwiąże). Rozwiązanie amerykańskie z kolei charakteryzuje się dużym poziomem decentralizacji. Tam ludzie powołują instytucje, które mają im pomóc zrealizować wspólnie to, czego nie są w stanie dokonać w pojedynkę. Instytucje te są powołane na mocy wspólnej, suwerennej decyzji równych sobie jednostek. Taka wizja wiąże się z tradycją amerykańskiego township i w jego ramach funkcjonującej samorządności, która ukształtowała nawyki, obyczaje, przyzwyczajenia polityczne Amerykanów zanim jeszcze zbudowali własne państwo. 


\section{RÓWNOŚĆ KONTRA WOLNOŚĆ 6}

W takim stanie rzeczy pojawia zasadnicza sprzeczność dotycząca zorganizowanego w ramach państwa „nowego” społeczeństwa, a mianowicie konflikt, jaki zachodzi pomiędzy wolnością a równością. Od tej chwili idea równości przenika wszystkie stosunki społeczne, z perspektywy jednostki nawet te najmniej istotne. Zabezpieczeniem przed jej negatywnymi skutkami ma być wolność, jednakże często rozumiana zbyt formalnie jako katalog praw politycznych (czasami tylko wyborczych), na podstawie których powoływane są do życia instytucje mające być jej urzeczywistnieniem.

Równość warunków przekonuje każdego człowieka - stwierdza Manent - a "dogmat” suwerenności ludu mu nakazuje - aby widział w sobie własnego suwerena, a więc w ostatecznym wymiarze także sędziego w stosunku do ludzi, idei i rzeczy. Oczywiście każdy ku temu skłania się z natury. Jednakże prawo, wraz ze społeczeństwem, które ono reguluje, dodaje tutaj do sugestii natury swój autorytet. Mówi mu ono coś, co do czego on miałby poważne wątpliwości: że jest tak dobry jak każdy inny człowiek, a prawo mu to udowadnia obdarzając go rangą równą randze kogokolwiek z najwyższych władz Państwa. To, co szepce mu serce i głosi prawo, społeczeństwo wokół niego nieustannie neguje: niektórzy są bogatsi, potężniejsi od niego, niektórzy mają opinię mądrzejszych i inteligentniejszych. Sprzeczność między społeczną rzeczywistością a życzeniem, za którym stoi serce i prawo, pobudza oraz ożywia w każdym człowieku niszczącą namiętność: namiętność równości. Nie spocznie on, zanim społeczna rzeczywistość nie będzie zgodna z nim samym i z prawem (Manent, 1994, s. 155).

6 Dla zilustrowania powyższej tezy niech posłuży cytat z książki Tocqueville and the nature of democracy autorstwa P. Manenta: „Ponieważ równość kształtuje granice społecznej wrażliwości, skrajnie wysokie lub skrajnie niskie pozycje społeczne wydają się «przypadkowe». Nic nie świadczy o tym, że sumienie społeczne utrzymuje te ekstremalne pozycje na swoim miejscu. Kiedy Tocqueville przeciwstawia «wyimaginowaną równość» «prawdziwej równości», nie sugeruje, że ta równość jest fikcyjna lub iluzoryczna - wręcz przeciwnie. $Z$ tej perspektywy «zjawiskiem urojonym» jest «opinia publiczna» i wiemy, że w oczach Tocqueville'a opinia publiczna jest fundamentem społeczeństw demokratycznych. Co więcej, Tocqueville posuwa się nawet do stwierdzenia, że ta «wyobrażona równość» doprowadzi do wprowadzenia prawdziwej równości. Cała jego analiza sugeruje, że mimo formułowanych przez siebie zastrzeżeń, wierzy w taki obrót spraw. Ludzka świadomość determinuje ich istnienie (tłum. własne)" (por. Manent, 1996, s. 31). 
Dyskomfort, jaki odczuwa człowiek demokratyczny obserwując rzeczywistość, w której występują naturalne różnice między ludźmi z tytułu zamożności, inteligencji, szybko zostaje pokonany. Łagodzi go świadomość przypadkowości tych różnic oraz przekonanie, że postępujący proces równości je zniweluje i upodobni ludzi do siebie.

Skoro nikt nie będzie tedy różnił się od swych bliźnich - pisze Tocqueville - nikt nie będzie mógł sprawować władzy tyrańskiej. Ludzie będą doskonale wolni, ponieważ wszyscy będą całkowicie równi, i będą doskonale równi, ponieważ będą całkowicie wolni. Ku takiemu właśnie ideałowi zmierzają społeczeństwa demokratyczne (Tocqueville, 1996b, s. 103) ${ }^{7}$.

Tocqueville stwierdza - równi w wolności, wolni w równości, czyli podobni. Podobieństwo, jakie ludzie w demokracji odczuwają względem siebie, jest konsekwencją zmian, które zachodzą pod wpływem postępów równości. Prowadzi to do zwiększenia wrażliwości na krzywdę innych oraz stwarza poczucie solidarności z innymi zbliżonymi w swym statusie do nas. Ta empatia, wczucie się w los innego człowieka, nie jest w stanie zredukować naturalnych różnic. Tak więc jednostka targana jest przez dwie sprzeczne ze sobą w swej istocie namiętności - dążenie do wyeliminowania różnic dzielących ludzi z jednej strony, z drugiej zaś pogodzenie się z ich istnieniem, a w niektórych przypadkach wręcz ich podkreślanie. Społeczeństwo demokratyczne bowiem jest również areną walki i konkurencji między jednostkami. Konkurencja związana z działaniem rynku prowadzi do jeszcze głębszego zróżnicowania społeczeństwa w wymiarze posiadania. Dylemat, jaki do rozstrzygnięcia ma „człowiek demokratyczny", zawiera się w pytaniu o to, czy akceptować konkurencję pogłębiającą tylko różnice między ludźmi, czy też konsekwentnie realizować postulaty równości, których urzeczywistnienie wcieli w życie zasadę podobieństwa. Odpowiedź jest dość oczywista.

Akceptacja konkurencji - konstatuje Manent-stanowi w istocie niezwykle kruchą dyspozycję psychiczną: polega na jednoczesnym uznaniu

$7 \quad$ „Nul ne différant alors de ses semblables, personne ne pourra exercer un pouvoir tyrannique; les hommes seront parfaitement libres, parce qu'ils seront tous entièrement égaux; et ils seront tous parfaitement égaux parce qu'ils seront entièrement libres. C'est vers cet idéal que tendent les peuples démocratiques" (por. Tocqueville, 1952b, s. 93). 
i odrzuceniu nierówności. W społeczeństwie demokratycznym opinia publiczna przeniknięta poczuciem podobieństwa ludzi do siebie, traktująca nierówności jako coś zasadniczo akcydentalnego, w sposób naturalny - jeśli tak można powiedzieć - wzmacnia odruch odrzucający, a więc w sposób naturalny daje przewagę tej części duszy, która odrzuca nierówności, choćby były akcydentalne: uznać nierówności za „zasadniczo akcydentalne" to właściwie już je odrzucić (Manent, 1994, s. 157).

W świetle powyższych słów, rozstrzygnięcie dylematu „człowieka demokratycznego" jest zabiegiem dość prostym. Skoro różnice między ludźmi są dziełem przypadku i jeszcze na domiar stoją w sprzeczności z "odwiecznym” dążeniem do równości, należy je po prostu odrzucić. Taka jednak forma kontestacji nierówności rodzi zasadniczy problem - jak pozbyć się natrętnego przekonania, że zawsze będą jacyś „,inni”, bogatsi, mądrzejszy i bardziej zadowoleni z życia od nas. Jak przełamać fatalizm ,ja - inni". Narzędziem służącym do zakwestionowania tego podziału jest władza, która będzie gwarantem równości pomiędzy jednostkami i stworzy warunki, w których nikt nie będzie specjalnie wyrastał ponad innych. Legitymację władza ta otrzyma na podstawie zrzeczenia się przez wszystkich obywateli części suwerennych praw na jej rzecz. Pozbędą się oni swoich uprawnień, wiedząc że inni też zrezygnują z przysługujących im prerogatyw (Manent, 1994, s. 158).

\section{CZŁOWIEK MASOWY WCHODZI NA SCENĘ HISTORII $^{8}$}

Scedowanie swoich uprawnień na rzecz władzy może mieć jednak inną poważną konsekwencję. Jego rezultatem będzie ujednolicenie

8 Stan ten znakomicie opisuje M. Oakshott w swojej książce Wieża Babel i inne eseje: „Bieg nowoczesnej historii Europy zrodził postać, którą zwykliśmy nazywać «człowiekiem masowym». Mówi się, że jego pojawienie się jest najdonioślejszą i najbardziej dalekosiężną rewolucją czasów nowożytnych. Wierzy się, że przekształca nasz sposób życia, nasze kanony postępowania, nasze sposoby działania politycznego. Uznaje się w nim niekiedy z żalem arbitra smaku, dyktatora polityki, niekoronowanego króla świata nowoczesnego. W niektórych budzi lęk, w innych podziw, zastanowienie we wszystkich. Liczebność czyni z niego giganta; mnoży się wszędzie; widzi się w nim albo szarańczę, która obraca w pustynię żyzny dawniej ogród, albo dźwigar nowej i wspanialszej cywilizacji” (Oakeshott, 1999, s. 147). 
myślenia. Krótko rzecz ujmując, po prostu zagrożenie dla samej swobody myślenia.

W miarę jak ludzie się do siebie upodabniają - twierdzi Tocqueville dogmat głoszący równość ich inteligencji coraz silniej przenika ich poglądy (...). Podstawowe ludzkie poglądy stają się podobne do siebie w miarę upodabniania się ludzkich możliwości. Tak się, moim zdaniem, rzeczy mają w zasadzie i na trwałe, reszta to okoliczności i wydarzenia przypadkowe (...). W społeczeństwach demokratycznych nie tylko słabnie zaufanie do wyjątkowego rozumu pojedynczych jednostek, lecz (...), zanika ogólna idea przewagi intelektualnej, jaką jeden człowiek mógłby mieć nad innymi (Tocqueville, 1996b, s. 271) ${ }^{9}$.

Mechanizmem, który zabezpiecza swobodę myślenia, jest debata, polemika, spór. Walka przeciwstawnych racji, wzajemne ścieranie się umysłów tworzą odpowiedni grunt dla niezależnego myślenia. A jeżeli:

możliwości są niemal identyczne człowiek z trudem tylko pozwala drugiemu człowiekowi coś sobie wytłumaczyć. Skoro wszyscy uważają się za podobnych, wspólnie nauczyli się podobnych rzeczy i prowadzą podobny rodzaj życia, to nie są skłonni brać jednego spośród siebie za przewodnika i ślepo go słuchać. Nie wierzy się słowom człowieka nam podobnego lub równego (Tocqueville, 1996b, s. 96) ${ }^{10}$.

9 „À mesure que les hommes se ressemblent davantage, le dogme de l'égalité des intelligences s'insinue peu à peu dans leurs croyances, et il devient plus difficile à un novateur, quel qu'il soit, d'acquérir et d'exercer un grand pouvoir sur l'esprit d'un peuple. Dans de pareilles sociétés, les soudaines révolutions intellectuelles sont donc rares; car, si l'on jette les yeux sur l'histoire du monde, l'on voit que c'est bien moins la force d'un raisonnement que l'autorité d'un nom qui a produit les grandes et rapides mutations des opinions humaines.(...) Ce n'est pas que les hommes des démocraties soient naturellement fort convaincus de la certitude de leurs opinions, et très fermes dans leurs croyances; ils ont souvent des doutes que personne à leurs yeux, ne peut résoudre. Il arrive quelquefois dans ce temps-là que l'esprit humain changerait volontiers de place; mais, comme rien ne le pousse puissamment ni ne le dirige, il oscille sur lui-même et ne se meut pas. Lorsqu'on a acquis la confiance d'un peuple démocratique, c'est encore une grande affaire que $\mathrm{d}^{\prime}$ obtenir son attention. Il est très difficile de se faire écouter des hommes qui vivent dans les démocraties, lorsqu'on ne les entretient point d'eux-mêmes. Ils n'écoutent pas les choses qu'on leur dit, parce qu'ils sont toujours fort préoccupés des choses qu'ils font." (por. Tocqueville, 1952d, s. 95-96).

Zob. Tocqueville, 1952d, s. 96. 
Jeżeli człowiek nie słucha drugiego człowieka, to tym samym niszczy podstawy jakiejkolwiek debaty, wymiany czy aktywności intelektualnej. Jak ma zaufać komuś innemu, skoro ten drugi jest tyle samo wart co on; wszak ukształtowały go te same nauki, obyczaje i przyzwyczajenia. Jeżeli zatem nie ufa on sobie ani drugiemu człowiekowi, podobnemu do siebie, to swoje zaufanie musi ulokować w kimś trzecim; w ilości, tym co tworzą wszyscy, czyli masie. Skoro wszyscy jesteśmy do siebie podobni, to jako społeczeństwo możemy wydać sprawiedliwy osąd. Nieograniczona wiara w nieomylność opinii publicznej bierze się z przekonania, że jeśli nasze umysły są do siebie podobne, to mechanizm odkrywania i docierania do prawdy musi opierać się na wszystkich tworzących społeczeństwo ludziach. Ta bezkrytyczna wiara w „prawdotwórczą" siłę „masy” prowadzi do „absolutnych” rządów większości, które Tocqueville nazywa „nowym despotyzmem” lub „wszechwładzą większości” (Tocqueville, 1996a, s. 252-260) ${ }^{11}$.

Dla Tocqueville'a - pisze Paweł Marczewski - problematyczne są nie tylko konsekwencje ekonomicznego ujednolicenia, ale i polityczne skutki isonomii, pełnego zrównania w prawach, dzięki któremu lud zyskuje suwerenność. Nawet gdy w rozległym państwie nie wszyscy czynnie angażują się w sprawy publiczne, ostatecznym suwerenem pozostaje lud. Nie przestaje być nim również wtedy, gdy kierownictwo spraw wspólnych oddaje wspomnianej wcześniej opiekuńczej władzy, która jednocześnie mu schlebia i nim pogardza. Zachowuje pozory równości i swobód, by jednocześnie łagodnie ingerować we wszystkie dziedziny życia. Tej ostatniej możliwości jednak nie przewidzieli ani Rzymianie, ani Grecy. Ci pierwsi w ogóle nie uważali pełnej suwerenności ludu za warunek utrzymywania równości wobec prawa, która z kolei była niezbędną gwarancją libertas. Ci drudzy sądzili, że despotyczna władza musi łamać zasadę suwerenności ludu. (...) Radykalna odmienność władzy, która na kartach $O$ demokracji $w$ Ameryce bywa opatrywana mianem już to "demokratycznego despotyzmu”, już to „,władzy opiekuńczej”, polega na tym, iż czyni ona zadość formalnemu wymogowi utrzymania suwerenności ludu, by jednocześnie zniechęcać ludzi do korzystania z ich praw uczestnictwa w życiu politycznym (Marczewski, 2012, s. 72).

11 Zob. tamże, s. 76-83. 


\section{5. ŁAGODNY DESPOTYZM (DESPOTYZM ŁAGODNOŚCI) - PODSTĘPNE REGUŁY POLITYCZNEGO UBEZWŁASNOWOLNIENIA JEDNOSTKI}

Despotyzm ów wiąże się z ubezwłasnowolnieniem jednostki przez wszechobecna, ale jednak łagodną władzę, która z „ojcowską" troską pochyla się nad każdym potrzebującym pomocy i skwapliwie mu jej udziela. Rozwiązuje za nas wszystkie problemy, bylebyśmy zostawili jej szeroki margines do swobodnego działania i zanadto nie wtrącali się w jej sprawy. Za wszystkie zaś łaski i dobrodziejstwa, jakie na nas, zwykłych obywateli z jej strony spadaja, powinniśmy być wdzięczni i pod żadnym pozorem nie powinniśmy jakiegokolwiek z jej przedsięwzięć krytykować (Tocqueville, 1996b, s. 329-332) ${ }^{12}$. „Celem prawa - pisze Manent - zgodnie z tym, czego pragnie władza oraz obywatele, będzie niemal wyłącznie zmniejszenie okazji do widocznego cierpienia. Określenie «łagodny despotyzm» jest być może nieprecyzyjne: dla ludzi nastanie despotyzm łagodności" (Manent, 1994, s. 160). Wspomniana przez Manenta "łagodność" jest cechą charakterystyczną liberalizmu, który "troszczy się" o rozwój handlu oraz otacza opieką oświatę, stanowiące obok monteskiuszowskiego podziału władz filary myśli liberalnej. Zatem głównym zadaniem ustroju liberalnego jest stopniowe zmniejszanie poziomu cierpienia w społeczeństwie. Tocqueville w ślad za Monteskiuszem uważa, że państwo demokratyczne, czy też demokratyczne społeczeństwo, $\mathrm{z}$ biegiem czasu coraz bardziej będą kierować się przekonaniem o łagodzeniu rozmiarów ludzkiego cierpienia oraz wiara, że zabiegi te okażą się skuteczne.

Wraz z Tocqueville'em - pisze Manent - liberalizm przestaje już podkreślać konieczny i harmonijny rozwój równości oraz wolności, a koncentruje się odtąd na walce, jaką upodobanie do wolności toczy nie tyle przeciw równości, ile przeciw namiętności równości, walce, która nie wiadomo jak się zakończy, walce nierównej, gdyż wolność stanowi część sztuki demokracji, podczas gdy równość należy do jej natury (Manent, 1994, s. 161).

12 Zob. tamże, s. 146-148. 
Toqueville zdaniem Manenta w owym napięciu między równością, rozumianą jako „natura” demokracji, a wolnościa, interpretowaną jako jej "sztuka”, nawiązywał do znanej koncepcji filozofii politycznej, a mianowicie „stanu natury". Ów „stan natury”, w którym istnieje równość i brak jakiejkolwiek formy władzy w koncepcji liberalnej, jest hipotezą mającą uzasadniać abstrakcyjną (przeciwną naturze) zasadę reprezentacji, z której czerpie swoje uzasadnienie rząd przedstawicielski ( $w$ bardzo szerokim tego słowa znaczeniu). W liberalnym mechanizmie wyłaniania się z politycznego ładu, będąc jedynie początkowym założeniem, które stanowi podstawę całej misternej konstrukcji politycznej i jego rola na tym się kończy. Jest rodzajem fundamentu, na którym opiera się pierwotny porządek polityczny, a on bardzo szybko zostaje zastąpiony przez nową zasadę legitymującą ów polityczny porządek, której na imię suwerenność. Tocqueville zdaje się kwestionować owo uzasadnienie i proponuje na nowo zbadać relację między „naturą" a „sztuką” w demokracji. Twierdzi on, że „stan natury" nie jest warunkiem, który tworzy społeczeństwo demokratyczne, by po odegraniu właściwej dla siebie roli zniknąć. Wręcz przeciwnie, ów „stan natury”, w którym ludzie są wolni i równi oraz z racji posiadanej autonomii są w stanie wyłonić spośród siebie władzę, jest „,stanem właściwym” dla demokratycznego społeczeństwa ${ }^{13}$.

Pierwszy moment demokracji - konstatuje Manent - polega na wysiłku stworzenia prawdziwego "stanu natury", w oparciu o który ludzie mogą w końcu w sposób swobodny ukonstytuować się w wolnej wspólnocie politycznej (...). Pierwszy naturalny moment demokracji to ten, kiedy tworzy ona warunki wykreowania jedynego prawowitego społeczeństwa, warunki wykreowania samej siebie. Obserwowanie demokracji pokazuje więc Tocqueville'owi, iż to co liberalizm uznawał za ",hipotezę", ,"daną" czy założenie prawowitego porządku politycznego, winno być przedmiotem dążeń lub zostać

13 „Istnieją dwie bezwzględne różnice między rzeczywistością a procesem myślenia. Po pierwsze, stan natury w demokracji jest pewną formą ucywilizowania przyrody, podczas gdy tworzenie społeczeństwa bierze swój początek od teoretyków umowy społecznej. Można zauważyć, że przy braku stowarzyszenia cywilnego (w domyśle społeczeństwa) zagrożona byłaby sama cywilizacja. Można również dostrzec, że proces demokratyczny zawiera w sobie aktualny stan natury prowadzący do kryzysu cywilizacji w ogóle. Ta druga różnica jest o wiele ważniejsza (tłum. własne)" (por. Manent, 1996, s. 27). 
wykreowane czy skonstruowane. Stan natury nie jest początkiem politycznej historii człowieka, lecz raczej jego kresem, a przynajmniej horyzontem. Program liberalny, z tej racji, iż pragnie oprzeć się na równości „naturalnej”, otwiera więc właściwie tylko jedną historię: historię starań i postępu człowieka w dziele sztucznego wykreowania - dzięki suwerenności, jakiej nie ma w naturze - owej „naturalnej” równości, w oparciu o którą będzie on mógł zbudować w sposób całkowicie „racjonalny" $i$,„świadomy” prawowity porządek polityczny. Ponieważ natura ciągle tworzy nierówności, wpływy, zależności, ów "pierwszy" moment nigdy nie mija: będąc stałym tłem demokracji jest on jej "natura"; to w nim tkwi warunek wszelkiej konwencji i to on daje człowiekowi demokratycznemu poczucie życia w historii; on bowiem sprawia, iż człowiek ten żyje wewnątrz schematu, którego jest jednocześnie suwerennym panem i posłuszną materią (Manent, 1994, s. 162).

Myśl Tocqueville'a zinterpretowana przez Manenta ukazuje swoją głębię i niejednoznaczność. Jednak podstawowe napięcie, jakie dostrzegł Tocqueville, zawarte w paradoksie, że człowiek jest twórcą politycznego ładu, a w ramach pewnej wewnętrznej logiki jego suwerennym konstruktorem, oraz ograniczanym w swej niezależności mieszkańcem - nadal pozostaje w mocy. Tocqueville zostawił swoim potomnym "łamigłówkę" nie do rozwiązania. Może cały urok sformułowanej przez niego „zagadki” dotyczącej „natury" i „,sztuki” demokracji po prostu polega na tym, że nie ma ostatecznego rozwiązania. Człowiek musi zdawać sobie sprawę z zasadniczej sprzeczności, jaka zachodzi pomiędzy dążeniem do „wolności” a przeciwstawną mu namiętnością „pełnej równości”. W utrzymaniu właściwych proporcji pomiędzy tymi dwiema konkurencyjnymi ideami, zarazem niezbędnymi dla zaistnienia demokracji, zawarta jest bowiem nadzieja na zachowanie równowagi $\mathrm{w}$ ramach politycznego porządku; a co za tym idzie nadzieja na zapewnienie jego twórcy człowiekowi - jednostce - pełnej swobody w korzystaniu z dobrodziejstw płynących zarówno z wolności, jak i równości. Jednak doświadczenia drugiej dekady XXI w. uświadamiają nam, że ta twórcza siła może zamienić się w siłę destrukcyjna, istnieje bowiem ryzyko - jak pisze Mounk - że:

liberalne demokracje mogą zostać wypaczone na dwa sposoby. Demokracje mogą być nieliberalne. Jest to szczególnie prawdopodobne $\mathrm{w}$ miejscach, gdzie większość ludzi opowiada się za 
podporządkowaniem niezależnych instytucji kaprysom władzy wykonawczej lub ograniczeniem praw mniejszości, których nie lubią. $\mathrm{Z}$ drugiej strony, ustroje liberalne mogą być niedemokratyczne pomimo przeprowadzania regularnych, opartych na zasadach współzawodnictwa wyborów. Jest to szczególnie prawdopodobne w sytuacji, gdy system polityczny jest tak spaczony na korzyść elit, że wybory rzadko przy czyniają się do tego, żeby poglądy społeczne przekładały się na politykę społeczną. Obawiam się, że właśnie to wydarzyło się w wielu częściach świata w ciągu ostatnich kilkudziesięciu lat. Moim zdaniem spoiwo liberalizmu i demokracji stanowił zestaw technologicznych, gospodarczych i kulturowych warunków wstępnych. Dziś to spoiwo szybko słabnie. W rezultacie rozpada się demokracja liberalna - unikalne połączenie praw jednostki i rządów ludu - która od dawna charakteryzuje większość systemów w Ameryce Północnej i Europie Zachodniej. Zamiast niej powstają dwie nowe formy ustroju: „demokracja nieliberalna”, czyli demokracja bez praw, oraz „liberalizm niedemokratyczny", czyli prawa bez demokracji. Kiedy zostanie spisana historia XXI wieku, rozkład demokracji liberalnej na te dwie części składowe najprawdopodobniej zajmie w niej centralne miejsce" (Mounk, 2019, s. 42-43).

\section{BibLIOGRAFIA}

Manent, P. (1996). Tocqueville and the nature of democracy. Londyn: Wydawnictwo Rowmann \& Littlefield Publishers, Inc.

Manent, P. (1994). Intelektualna historia liberalizmu. Kraków: Wydawnictwo Arcana.

Marczewski, P. (2012). Uczynić wolność nieuchronna. Wątki republikańskie $w$ myśli Alexisa de Tocqueville'a. Warszawa: Wydawnictwo IFIS PAN.

Mounk, Y. (2019). Lud kontra demokracja. Dlaczego nasza wolność jest wniebezpieczeństwie i jak ja ocalić. Warszawa: Wydawnictwo: Fundacja Kultura Liberalna.

Oakeshott, M. (1999). Wieża Babel i inne eseje. Warszawa: Wydawnictwo Aletheia.

Tocqueville, A. de (1996a). O demokracji w Ameryce. Kraków: Wydawnictwo Znak.

Tocqueville, A. de (1996b). O demokracji w Ameryce. Kraków: Wydawnictwo Znak.

Tocqueville, A. de (1952a). De la démocratie en Amérique, Première partie. Paris: Wydawnictwo Gallimard.

Tocqueville, A. de (1952b). De la démocratie en Amérique, Deuxième partie. Paris: Wydawnictwo Gallimard. 
Tocqueville, A. de (1952c). De la démocratie en Amérique, Première et deuxième parties. Paris: Wydawnictwo Gallimard.

Tocqueville, A. de (1952d). De la démocratie en Amérique, Troisième et quatrième parties. Paris: Wydawnictwo Gallimard.

\section{Copyright and License}

This article is published under the terms of the Creative Commons Attribution - NoDerivs (CC BY- ND 4.0) License http://creativecommons.org/licenses/by-nd/4.0/ 